\title{
Drinking water system treatment and contamination in Shatila Refugee Camp in Beirut, Lebanon
}

S. Khoury ${ }^{1,2}$, T. Graczyk, G. Burnham ${ }^{3}$, M. Jurdi ${ }^{4}$ and L. Goldman ${ }^{5}$

$$
\begin{aligned}
& \text { معالجة منظو مة مياه الشرب و التلوثُ في مخيم شاتيلا للاجئين في بيروت بلبنان }
\end{aligned}
$$

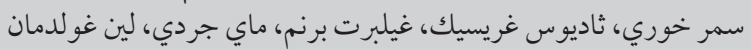

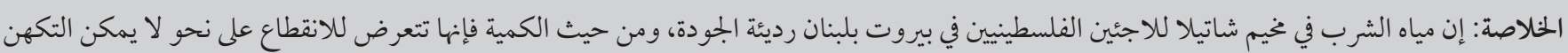

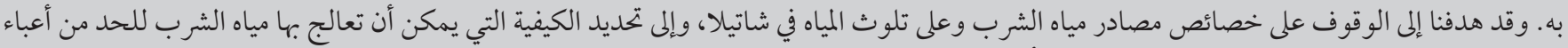

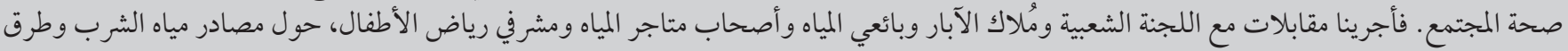

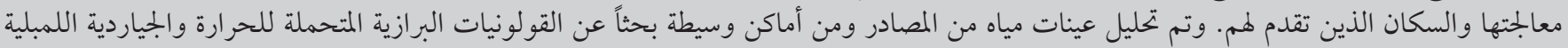

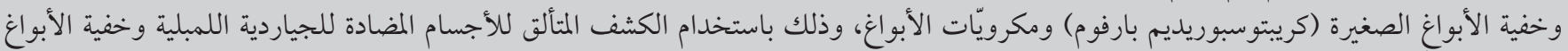

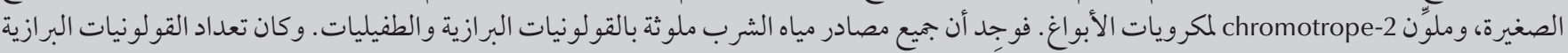

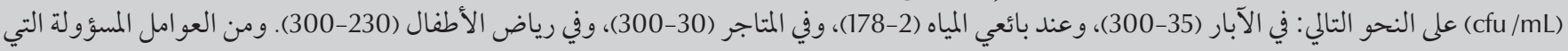

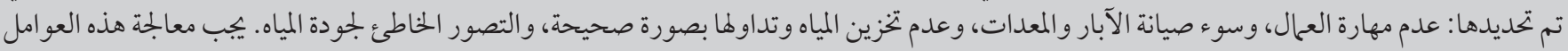

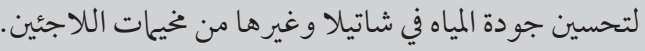

ABSTRACT Drinking water at Shatila Palestinian Refugee Camp in Beirut, Lebanon is of poor quality and unpredictably intermittent quantity. We aimed to characterize drinking water sources and contamination at Shatila and determine how drinking water can be managed to reduce community health burdens. We interviewed the Popular Committee, well owners, water vendors, water shopkeepers and preschool administrators about drinking water sources, treatment methods and the population served. Water samples from the sources and intermediaries were analysed for thermotolerant faecal coliforms (FCs), Giardia lamblia, Cryptosporidium parvum and microsporidia, using immunofluorescent antibody detection for $G$. lamblia and C. parvum, and chromotrope-2 stain for microsporidia. All drinking water sources were contaminated with FCs and parasites. FC counts (cfu/mL) were as follows: wells (35-300), water vendors (2-178), shops (30-300) and preschools (230-300). Responsible factors identified included: unskilled operators; improper maintenance of wells and equipment; lack of proper water storage and handling; and misperception of water quality. These factors must be addressed to improve water quality at Shatila and other refugee camps.

Traitement et contamination des systèmes d'eau potable dans le camp de réfugiés de Chatila à Beyrouth, au Liban

RÉSUMÉ L'eau potable dans le camp de réfugiés palestiniens de Chatila, au Liban, est de mauvaise qualité et n'est disponible qu'en quantités imprévisibles et irrégulières. La présente étude avait pour objectif d'identifier les sources d'eau potable et de contamination à Chatila, et de déterminer la façon dont l'eau potable peut être gérée pour réduire la charge des problèmes de santé communautaires. Nous avons interrogé le Comité populaire, les propriétaires de puits, les vendeurs d'eau ambulants, les marchands d'eau, les responsables de structures préscolaires sur les sources d'eau potable, les méthodes de traitement et la population desservie. Des échantillons d'eau à la source et au niveau des intermédiaires ont été analysés afin de détecter la présence de coliformes thermotolérants, de Giardia lamblia, de Cryptosporidium parvum et de microsporidies, à l'aide de la recherche des anticorps par immunofluorescence pour G. lamblia and C. parvum, et de la coloration au chromotrope $2 \mathrm{R}$ pour les microsporidies. Toutes les sources d'eau potable étaient contaminées par des coliformes thermotolérants et des parasites. Les taux ( $\mathrm{ufc} / \mathrm{ml})$ de coliformes thermotolérants étaient les suivants : puits (35-300), vendeurs d'eau ambulants (2-178), commerces (30-300) et structures préscolaires (230-300). Les facteurs responsables identifiés incluaient les points suivants : des opérateurs non formés, une mauvaise maintenance des puits et des équipements, un stockage et une manutention de l'eau inappropriés, et une perception erronée de la qualité de l'eau. Il est nécessaire d'agir sur ces facteurs afin d'améliorer la qualité de l'eau à Chatila et dans les autres camps de réfugiés.

${ }^{1}$ Formerly, Johns Hopkins University, Bloomberg School of Public Health, Department of Environmental Health Sciences. ${ }^{2}$ Association of Schools and Programs of Public Health Fellow, US Environmental Protection Agency, Office of Children's Health Protection, Washington, United States of America. ${ }^{3}$ Department of International Health, Baltimore, United States of America. ${ }^{4}$ American University, Beirut, Lebanon. ${ }^{5}$ George Washington University, Milken Institute School of Public Health, Department of Environmental and Occupational Health, Washington DC, United States of America (Correspondence to: L.R. Goldman: goldmanl@gwu.edu).

Received: 26/06/15; accepted: 03/07/16 


\section{Introduction}

In 2015, it was estimated that 663 million people worldwide still use unimproved drinking water sources, including unprotected wells and springs and surface water (1). In 2012, 502000 deaths from diarrhoea $(\sim 1000 /$ day $)$ were estimated to be caused by inadequate drinking water. Among children aged $<5$ years, 361000 deaths could have been prevented, representing 5.5\% of deaths in that age group (2).

Although reliable data are difficult to obtain, Palestinian camps in Lebanon experience frequent outbreaks of waterborne diseases, which lead to unnecessary death and disability among the vulnerable members of this population (3). There are $\sim 425000$ Palestinian refugees in Lebanon inhabiting 12 refugee camps, including Shatila (4). These camps were established after 1948, when Israel occupied Palestine and $>1$ million Palestinians became refugees in surrounding countries: Lebanon, Syrian Arab Republic, Jordan, Iraq and Egypt. The camps lack proper infrastructure and suffer from overcrowding, poverty and environmental degradation. The refugees have limited employment opportunities, scarce economic resources, and poor access to basic health and social services (4).

Shatila Camp was established in 1949, $11 \mathrm{~km}$ from the centre of Beirut, with an area of $1 \mathrm{~km}^{2}$, and houses $>12$ 000 people (4). The crowded living conditions combine with the inadequate water and sanitation infrastructure to create an environment conducive to adverse health conditions $(1,5)$. Prior efforts to ensure safe drinking water from the Municipality of Beirut (MB) network were thwarted by illegal diversions of the water. In Shatila, drilled wells within the camp provide water for drinking and other domestic purposes (6). These wells are managed by entrepreneurs who sell the water to residents, and distribute it as drinking water to households (M. Yassin, personal communication, October 2008).

The presence of faecal coliform (FC) bacteria in water is often used as an indicator of recent faecal contamination, which increases the probability that pathogens are present (7). Although FCs may be pathogenic, most often they are not, and other assessments are required to confirm if pathogenic bacteria, viruses and parasites are present.

Theparasites Giardialamblia, Cryptosporidium parvum and microsporidia are persistent in water (8) and resistant to the disinfectants commonly used in drinking-water treatment $(9,10)$. They can remain viable in surface and tap water environments for several weeks to months where environmental conditions are adequate for parasite survival (11). This is important because drinking water, when contaminated, can become a significant source of infection in children.

G. lamblia and C. parrum infections are prevalent among children worldwide in industrialized and developing countries (12). Transmission is mainly through contaminated water. The resulting gastrointestinal infections can cause severe diarrhoea and contribute to growth and nutritional disorders (13). Giardiasis is a gastroenteritic disease that is common in developing countries, with an estimated prevalence of $20-30 \%$ in children aged $<10$ years (14). The global burden of disease from giardiasis and other parasite infections in children is not well understood but is large, and is especially severe among children in less-developed countries (15). Children with severe G. lamblia and C. parvum gastroenteritis may die from dehydration or suffer chronic infections that have negative cognitive and growth impacts. These infections cause significant morbidity and mortality worldwide and are associated with poverty, therefore, they are included in the World Health Organization
(WHO) Neglected Diseases Initiative (16).

The present study was a community assessment of the drinking water system in Shatila Camp. We measured contamination at each point in the system through analysis of thermotolerant FCs, as well as G. lamblia, C. parvum and microsporidia.

\section{Methods}

\section{Ethical considerations}

The study protocol was approved by the Institutional Review Board (IRB) of the American University in Beirut (AUB) and the Johns Hopkins School of Public Health (JHSPH), in Baltimore, Maryland. Permission to carry out all aspects of the research was obtained from the Popular Committee (PC) and other community leaders at Shatila Refugee Camp. An informed consent statement was translated into Arabic, approved by the IRB, and included with the survey instrument. Before collecting any data, the interviewer read the informed consent statement in its entirety to the interviewee.

\section{Interviews}

A map of the camp was created and a study team walked through the camp identifying the number and location of the water sources, vendors, shops, preschools, the municipal tap and possible informants. Interviews were conducted at various levels: $\mathrm{MB}$, the $\mathrm{PC}$, water vendors, water shops and preschools. A structured interview elicited information about sources of drinking water, treatment modes, and the population served. Drinking water was defined as water available for drinking. Service water was defined as water available for domestic purposes other than drinking.

\section{Sampling}

Sampling was carried out from September 2008 to January 2009. Sampling frequency was determined by the 
availability of the operators, time and resources. Water samples were collected at the public and private wells and at the municipal tap several times over 5 months. Samples were also tested in the field for residual chlorine using test kits (Hach, Loveland, CO, USA) (17).

\section{Thermotolerant FC analysis}

One hundred and thirty-one water samples $(100 \mathrm{~mL})$ were collected in sterile 4 oz bottles containing $0.1 \mathrm{~mL}$ $10 \%$ sodium thiosulfate solution, sealed, kept on ice at $1-4{ }^{\circ} \mathrm{C}$, and transported to the laboratory at AUB. Upon receipt, the laboratory personnel checked to ensure that the samples were properly collected, labelled, preserved and intact (unopened). The samples were logged, temperature was recorded and analyses were conducted. Standard methods (18) were followed using membrane filtration followed by incubation on selective media at $44-45^{\circ} \mathrm{C}$; colonies were counted after 48 hours and data were reported as $\mathrm{cfu} / 100 \mathrm{~mL}$ (19). Results were then compared with the standard of the Lebanon Ministry of the Environment (20), which is the same as the WHO guideline that requires drinking water to be free from FCs (19).

\section{Parasite analysis}

Fifty-five water samples for parasite analysis were collected in 1-L amber glass bottles with $1 \mathrm{~mL} \mathrm{75 \%} \mathrm{ethanol}$ preservative added, sealed, stored at $1-4$ ${ }^{\circ} \mathrm{C}$ and transported to AUB for refrigeration for 60-90 days. These samples were prepared via membrane filtration with polycarbonate membrane filters (47 mm), with 2.0 - and $10-\mu \mathrm{m}$ pores. The supernatant was discarded and the remaining $1 \mathrm{~mL}$ fluid was further processed by sugar flotation (21) by adding 7-8 $\mathrm{mL}$ sucrose solution to 1 $\mathrm{mL}$ sample that was then vortexed. The solution was then centrifuged for 10 minutes at $139 \times g$. The top $1 \mathrm{~mL}$ was removed, placed in a tube and centrifuged at $2432 \times g$ for 5 minutes. Ethanol ( $1 \mathrm{~mL}$ at $75 \%$ ) was added to the sugar solution, which was refrigerated and later shipped to the laboratories at JHSPH.

Analysis of the samples was conducted using fluorescein isothiocyanate (FITC)-conjugated combination of monoclonal antibodies (mAbs) against the cell wall antigens of G. lamblia and C. parvum from the MERIFLUOR Crypto/Giardia test kit (Meridian, North Jackson, OH, USA), and by chromotrope-2 stain for detection of microsporidia (21). Viability was assessed using probes synthesized at Johns Hopkins University as previously described (22) using fluorescence in situ hybridization (FISH) and FITCconjugated mAbs. An epifluorescent microscope, dry 60x objective and BP490 exciter filter were used to count the viable (fluorescing) G. lamblia cysts, C. parvum oocysts and microsporidia spores.

\section{Statistical analysis}

Data analysis was performed using Stata version 8. Descriptive statistics (means and frequencies) were calculated and histograms assessed the distribution of continuous variables. Scatterplots displayed the changes in concentrations of FCs with time for the different water sources. Boxplots compared the distribution of FCs for each frequency of cleaning categories. $\chi^{2}$ tests were carried out to determine associations between FC levels and the parasites variables.

\section{Results}

\section{Drinking water sources}

Shatila had 4 wells where water was extracted and distributed to the various water vendors for further treatment and distribution as drinking water. A few water vendors occasionally tested for turbidity or total dissolved solids, but overall, drinking waterwas nottested prior to distribution. The United Nations Relief and Works Agency (UNRWA) and the PC reported that the sewerage system was poorly functioning and the potential for cross-contamination was high, given the sandy soil. The water was reported to be turbid and hard.

The physical assessment identified 8 water vendors, 55 water shops (with closed plastic water storage tanks), 7 preschools, 1 nursery (that supplied drinking water to young children), and 1 municipal tap. People were seen at the water tap collecting water. There were 2 public groundwater wells (Wells 1 and 2, 40 and 35 m deep) and 2 private wells (Wells 3 and 4, both 45 m deep) supplying water to the camp. Water from these wells was pumped directly into pipes that fed rooftop tanks on buildings and/ or into water vendor shops for further treatment to render the water potable. Wells 1 and 2 lacked cap and casing protection but were locked. Well 4 was visibly poorly maintained (rubbish around the well, lack of well protection, and rusted metal) and subject to surrounding potential pollutants.

We learned that a municipal water pipe extended $16 \mathrm{~km}$ from the MB headquarters to about $2 \mathrm{~km}$ from Shatila. $\mathrm{MB}$ chlorinated this water prior to distribution. However, illegal diversions, combined with poorly maintained and leaking pipes have resulted in sewage cross-contamination as well as reduced water delivery. This was of particular significance because the water was not further treated in the camp.

The 8 water vendors reported treating and delivering the water to their customers. The vendors operated without any permits nor supervision; they claimed using reverse osmosis and UV light disinfection among other techniques such as chlorination. Subsequent sampling proved that some vendors stopped chlorinating the water, citing: consumer complaints of sour tea taste; concerns that chlorine ruined their expensive equipment; and community beliefs that chlorine stripped water of its nutrients.

Of the 55 identified water shops, 31 (56\%) shopkeepers were interviewed. 
None of the water shops further treated the water because they thought the water obtained was already treated.

The 7 preschools received drinking water from inside and outside the camp. These schools also used service water to wash food and utensils consumed by the students.

\section{Thermotolerant FCs}

A total of 131 samples were collected for FC analysis. Individual sample results are provided in the Supplementary Tables; means and ranges are provided in Table 1. All 4 wells were contaminated with FCs, and FC levels did not appear to follow a pattern during the study (Supplementary Table 1). The municipal tap was sampled 6 times; 2 were FC-free with a mean of $52 \mathrm{cfu} / 100$ $\mathrm{mL}$ (range: $0-300 \mathrm{cfu} / 100 \mathrm{~mL}$ ) (Table 1 and Supplementary Table 2). For the 8 water vendors. FC contamination was identified in $75 \%$ of these samples, with an overall mean of $43 \mathrm{cfu} / 100 \mathrm{~mL}$ (range: 0-300 cfu/100 mL) (Table 1 and Supplement Table 3).

Most of the 31 water shops had water samples that were contaminated with FCs. Seven samples yielded concentrations of $\geq 300 \mathrm{cfu} / 100 \mathrm{~mL} ; 23$ ranged between 1 and $299 \mathrm{cfu} / 100$ $\mathrm{mL}$; and 3 were free of organisms ( $\mathrm{Ta}$ ble 1 and Supplement Table 4). No relationship was found between levels of FC contamination and the frequency with which water shop owners reported cleaning the water tanks. For example, one of the shops that yielded an FC count of 0 stated that they cleaned the tank only once a year, supporting the possibility that the tanks were not adequately cleaned, widening the potential of introducing further contaminants.

Table 1 and Supplement Table 5 show that all preschools except Preschool 5 had FC-contaminated drinking water $(\mathrm{cfu} / \mathrm{mL}$ : range $=0-300$, average $=177$ and median $=191)$; and service water $(\mathrm{cfu} / \mathrm{mL}$ : range $=$
$12-300$, average $=242$ and median $=$ 300). In some schools, drinking water had higher FC levels than service water samples. Overall, the average ranges of FC in cfu/ml were: wells (35-300), water vendors (2-178), shops (30-300) and preschools (230-300) (Table 1).

\section{Parasites}

Individual parasite results are provided in the Supplementary Tables. FC contamination was often accompanied by the presence of one or more parasites; most frequently, G. lamblia or C. parvum, which were found ubiquitously in camp water (Table 1). There was no correlation between FC colony counts and parasite counts.

Table 2 displays the percentages of samples that tested positive for parasites. G. lamblia, C. parvum and microsporidia were found in $55 \%, 51 \%$ and $5 \%$ of the samples, respectively. A strong positive association was found between the presence of FCs and parasites (Pearson's $\chi^{2}$

\begin{tabular}{|c|c|c|c|c|c|}
\hline Water source & No. of samples & $\begin{array}{l}\text { C. parvum } \\
\text { (counts/L) }\end{array}$ & $\begin{array}{l}\text { G. lamblia } \\
\text { (counts/L) }\end{array}$ & $\begin{array}{l}\text { Microsporidia } \\
\text { (counts/L) }\end{array}$ & $\begin{array}{c}\text { FCs } \\
(\mathrm{cfu} / \mathrm{mL})\end{array}$ \\
\hline Well 1 & 4 & $1(0-2)$ & $1(0-1)$ & $1(0-3)$ & $300(300-300)$ \\
\hline Well 2 & 4 & $1(0-3)$ & $1(0-1)$ & 0 & $108(5-300)$ \\
\hline Well 3 & 2 & $1(0-2)$ & $1(1-1)$ & 0 & $35(25-44)$ \\
\hline Well 4 & 1 & 0 & 0 & 0 & 64 \\
\hline Vendor 1 & 4 & $2(0-5)$ & $2(0-5)$ & $0.5(0-2)$ & $30(5-68)$ \\
\hline Vendor 2 & 3 & $1(0-3)$ & $0.7(0-1)$ & 0 & $54(16-88)$ \\
\hline Vendor 3 & 6 & $1.2(0-3)$ & $1(0-3)$ & $0.5(0-3)$ & $178(8-300)$ \\
\hline Vendor 4 & 4 & $1(0-3)$ & $0.25(0-1)$ & 0 & $2(0-3)$ \\
\hline Vendor 5 & 6 & $0.5(0-2)$ & $0.5(0-1)$ & 0 & $18(0-64)$ \\
\hline Vendor 6 & 3 & $1.3(0-3)$ & $0.7(0-1)$ & 0 & $9(0-27)$ \\
\hline Vendor 7 & 4 & $1.5(0-4)$ & $0.5(0-1)$ & 0 & $49(0-107)$ \\
\hline Vendor 8 & 2 & $1.5(1-2)$ & 0 & 0 & $2(0-3)$ \\
\hline Shop 22 & 1 & 8 & 3 & 0 & 45 \\
\hline Shop 15 & 1 & 3 & 0 & 0 & 300 \\
\hline Shop 1 & 1 & 1 & 0 & 0 & 30 \\
\hline Shop 2 & 1 & 5 & 1 & 0 & 30 \\
\hline Preschool 2 & 2 & $0.5(0-1)$ & $0.5(0-1)$ & 0 & $230(159-300)$ \\
\hline Preschool 3 & 3 & $0.7(0-1)$ & $0.7(0-2)$ & 0 & $300(300-300)$ \\
\hline
\end{tabular}

Results presented as mean (range).

aIncludes all samples with parasite as well as FC analysis.

$F C=$ faecal coliform. 


\begin{tabular}{|c|c|c|c|c|c|c|}
\hline & $\begin{array}{l}\text { Total +ve } \\
\text { Samples }\end{array}$ & Vendor & School & Well & Shop & Municipality \\
\hline No. of samples & & 32 & 5 & 11 & 4 & 3 \\
\hline $\mathrm{FC}+$ & 46 & $24(75 \%)$ & $5(100 \%)$ & 11 (100\%) & $4(100 \%)$ & $2(66 \%)$ \\
\hline FC-/parasite- & & $4(12.5 \%)$ & $\mathrm{NAb}$ & 0 & $\mathrm{NAb}$ & $1(33 \%)$ \\
\hline $\mathrm{FC}+/$ parasite + & & $15(46.9 \%)$ & $3(60 \%)$ & $6(54 \%)$ & $4(100 \%)$ & $2(67 \%)$ \\
\hline Any parasite+ & & $19(59 \%)$ & $3(60 \%)$ & $6(54 \%)$ & 4 (100\%) & $2(67 \%)$ \\
\hline C. parvum+ & 30 & $17(53 \%)$ & $3(60 \%)$ & $4(36 \%)$ & $4(100 \%)$ & $2(67 \%)$ \\
\hline G. lamblia+ & 28 & $16(50 \%)$ & $2(40 \%)$ & $6(54 \%)$ & $2(50 \%)$ & $2(67 \%)$ \\
\hline Microsporidia+ & 3 & $2(6 \%)$ & 0 & $1(9 \%)$ & 0 & 0 \\
\hline
\end{tabular}

ancludes all samples with parasite as well as FC analysis.

${ }^{b}$ Three water shop samples and 1 school sample were FC free and none of these had parasite analysis.

$F C=$ faecal coliform.

\begin{tabular}{|c|c|c|c|c|}
\hline Date sampled & $\begin{array}{l}\text { C. parvum } \\
\text { (count/L) }\end{array}$ & $\begin{array}{l}\text { G. lamblia } \\
\text { (count/L) }\end{array}$ & $\begin{array}{l}\text { Microsporidia } \\
\text { (count/L) }\end{array}$ & $\begin{array}{c}\text { FC } \\
(\mathrm{cfu} / \mathrm{mL})\end{array}$ \\
\hline \multicolumn{5}{|l|}{ Well 1} \\
\hline 18 Sep & 0 & 0 & 0 & $>300$ \\
\hline 23 Sep & NS & NS & NS & $>300$ \\
\hline 25 Sep & NS & NS & NS & $>300$ \\
\hline 6 Oct & 0 & 0 & 0 & 300 \\
\hline 6 Oct (duplicate) & 2 & 1 & 0 & $>300$ \\
\hline $3 \mathrm{Nov}$ & NS & NS & NS & 1 \\
\hline $6 \mathrm{Nov}$ & NS & NS & NS & 88 \\
\hline $17 \mathrm{Dec}$ & 2 & 1 & 3 & $>300$ \\
\hline \multicolumn{5}{|l|}{ Well 2} \\
\hline 18 Sep & 0 & 1 & 0 & $>300$ \\
\hline 23 Sep & NS & NS & NS & 51 \\
\hline 26 Sep & NS & NS & NS & 51 \\
\hline 6 Oct & 3 & 1 & 0 & 63 \\
\hline 6 Oct (duplicate) & 0 & 0 & 0 & 63 \\
\hline $3 \mathrm{Nov}$ & NS & NS & NS & 0 \\
\hline $6 \mathrm{Nov}$ & NS & NS & NS & $>300$ \\
\hline $17 \mathrm{Dec}$ & 0 & 0 & 0 & 5 \\
\hline \multicolumn{5}{|l|}{ Well 3} \\
\hline 18 Sep & 2 & 1 & 0 & 44 \\
\hline 26 Sep & NS & NS & NS & $>300$ \\
\hline 29 Oct & NS & NS & NS & $>300$ \\
\hline $3 \mathrm{Nov}$ & NS & NS & NS & 50 \\
\hline $6 \mathrm{Nov}$ & NS & NS & NS & 2 \\
\hline $7 \mathrm{Nov}$ & NS & NS & NS & 3 \\
\hline $17 \mathrm{Dec}$ & 0 & 1 & 0 & 25 \\
\hline \multicolumn{5}{|l|}{ Well 4} \\
\hline 18 Sep & 0 & 0 & 0 & 64 \\
\hline 26 Sep & NS & NS & NS & $>300$ \\
\hline 29 Oct & NS & NS & NS & $>300$ \\
\hline $3 \mathrm{Nov}$ & NS & NS & NS & 50 \\
\hline $7 \mathrm{Nov}$ & NS & NS & NS & 2 \\
\hline
\end{tabular}

$F C=$ faecal coliform; $N S=$ not sampled. 


\begin{tabular}{lcccc}
\hline Supplementary Table 2 FC and parasite levels in Shatila Refugee Camp municipal water supply, September-November 2008 \\
\hline Date sampled & $\begin{array}{c}\text { C. parvum } \\
\text { (count/L) }\end{array}$ & $\begin{array}{c}\text { G. lamblia } \\
\text { (count/L) }\end{array}$ & $\begin{array}{c}\text { Microsporidia } \\
\text { (count/L) }\end{array}$ & $\begin{array}{c}\text { FC } \\
\text { (cfu/mL) }\end{array}$ \\
23 Sep & 5 & 2 & 0 & $>300$ \\
26 Sep & NS & NS & NS & 4 \\
6 Oct & 0 & 0 & 0 & 0 \\
6 Oct (duplicate) & 1 & 1 & NS & 2 \\
14 Oct & NS & NS & NS & 0 \\
7 Nov & NS & NS & & 1 \\
\hline
\end{tabular}

$F C=$ faecal coliform; $N S=$ not sampled.

Supplementary Table 3 FC and parasite levels in Shatila Refugee Camp drinking water samples from vendors, September 2008-January 2009

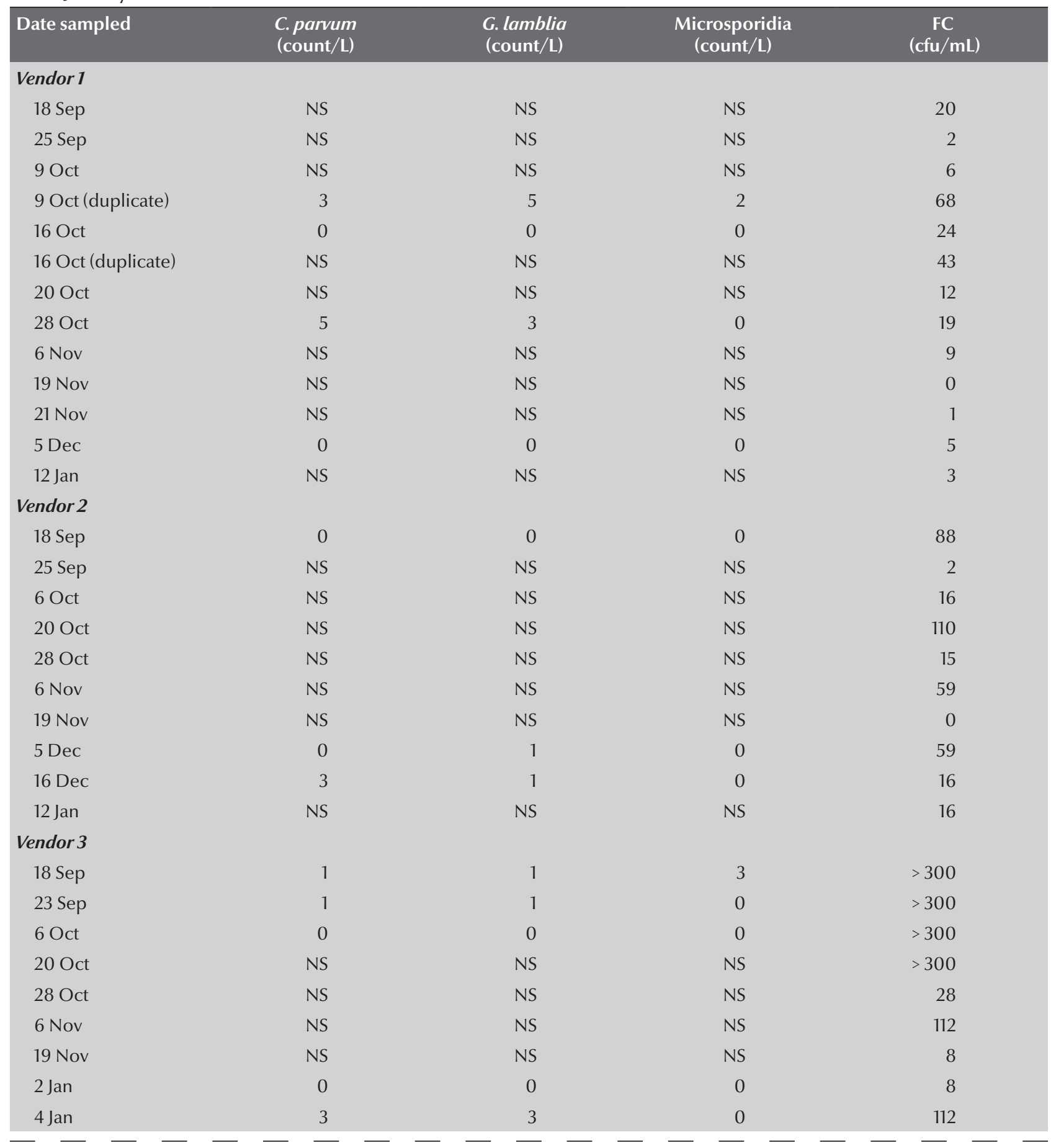




\begin{tabular}{|c|c|c|c|c|}
\hline \multicolumn{5}{|c|}{$\begin{array}{l}\text { Supplementary Table } 3 \text { FC and parasite levels in Shatila Refugee Camp drinking water samples from vendors, Septembe } \\
\text { 2008-January } 2009 \text { (continued) }\end{array}$} \\
\hline Date sampled & $\begin{array}{l}\text { C. parvum } \\
\text { (count/L) }\end{array}$ & $\begin{array}{l}\text { G. lamblia } \\
\text { (count/L) }\end{array}$ & $\begin{array}{l}\text { Microsporidia } \\
(\text { count/L) }\end{array}$ & $\begin{array}{c}\text { FC } \\
(\mathrm{cfu} / \mathrm{mL})\end{array}$ \\
\hline 12 Jan & 2 & 1 & 0 & 48 \\
\hline \multicolumn{5}{|l|}{ Vendor 4} \\
\hline 18 Sep & 1 & 0 & 0 & 3 \\
\hline 25 Sep & NS & NS & NS & 12 \\
\hline 6 Oct & 0 & 0 & 0 & 0 \\
\hline 20 Oct & NS & NS & NS & 0 \\
\hline 28 Oct & NS & NS & NS & 1 \\
\hline $3 \mathrm{Nov}$ & NS & NS & NS & 2 \\
\hline 19 Nov & NS & NS & NS & 0 \\
\hline $6 \mathrm{Dec}$ & 0 & 0 & 0 & 3 \\
\hline 6 Dec (duplicate) & 3 & 1 & 0 & 0 \\
\hline \multicolumn{5}{|l|}{ Vendor 5} \\
\hline 10 Sep & 1 & 1 & 0 & 3 \\
\hline 18 Sep & NS & NS & NS & 33 \\
\hline 18 Sep (duplicate) & 0 & 0 & 0 & 64 \\
\hline 25 Sep & NS & NS & NS & 3 \\
\hline 9 Oct & 0 & 0 & 0 & 0 \\
\hline 9 Oct (duplicate) & 0 & 0 & 0 & 0 \\
\hline 20 Oct & NS & NS & NS & 17 \\
\hline $3 \mathrm{Nov}$ & NS & NS & NS & 0 \\
\hline $6 \mathrm{Nov}$ & NS & NS & NS & 2 \\
\hline $19 \mathrm{Nov}$ & NS & NS & NS & 7 \\
\hline 12 Dec & 2 & 1 & 0 & 7 \\
\hline 2 Jan & 0 & 1 & 0 & 31 \\
\hline 12 Jan & NS & NS & NS & 64 \\
\hline \multicolumn{5}{|l|}{ Vendor 6} \\
\hline 18 Sep & NS & NS & NS & 0 \\
\hline 25 Sep & NS & NS & NS & 1 \\
\hline 9 Oct & 0 & 0 & 0 & 0 \\
\hline 10 Oct & 3 & 1 & 0 & 1 \\
\hline $3 \mathrm{Nov}$ & NS & NS & NS & 0 \\
\hline $6 \mathrm{Nov}$ & NS & NS & NS & 15 \\
\hline $3 \mathrm{Dec}$ & NS & NS & NS & 3 \\
\hline $4 \mathrm{Dec}$ & NS & NS & NS & 27 \\
\hline 16 Dec & 1 & 1 & 0 & 27 \\
\hline \multicolumn{5}{|l|}{ Vendor 7} \\
\hline 18 Sep & 0 & 0 & 0 & 87 \\
\hline 25 Sep & NS & NS & NS & 2 \\
\hline 9 Oct & 2 & 1 & 0 & 0 \\
\hline 16 Oct & NS & NS & NS & 30 \\
\hline $28 \mathrm{Oct}$ & NS & NS & NS & 107 \\
\hline 31 Oct & NS & NS & NS & 45 \\
\hline $3 \mathrm{Nov}$ & NS & NS & NS & 39 \\
\hline $19 \mathrm{Nov}$ & NS & NS & NS & 0 \\
\hline 5 Dec & 0 & 0 & 0 & 107 \\
\hline 16 Dec & 4 & 1 & 0 & 0 \\
\hline
\end{tabular}




$\begin{aligned} & \text { Supplementary Table } \mathbf{3} \text { FC and parasite levels in Shatila Refugee Camp drinking water samples from vendors, September } \\
& \text { 2008-January } 2009 \text { (concluded) }\end{aligned}$
\begin{tabular}{lcccc} 
Date sampled & $\begin{array}{l}\text { C. parvum } \\
\text { (count/L) }\end{array}$ & $\begin{array}{c}\text { G. lamblia } \\
\text { (count/L) }\end{array}$ & $\begin{array}{c}\text { Microsporidia } \\
\text { (count/L) }\end{array}$ & $\begin{array}{c}\text { FC } \\
\text { (cfu/mL) }\end{array}$ \\
7 Jan & NS & NS & NS & 2 \\
Vendor 8 & 1 & 0 & 0 & 0 \\
7 Nov & NS & NS & NS & 3 \\
3 Dec & 2 & 0 & 0 & 3 \\
8 Dec & & & & \\
\hline
\end{tabular}

$F C=$ faecal coliform; $N S=$ not sampled.

Supplementary Table 4 FC and parasite levels in Shatila Refugee Camp drinking water samples from water shops, September 2008-January 2009

\begin{tabular}{|c|c|c|c|c|}
\hline Date sampled & $\begin{array}{l}\text { C. parvum } \\
\text { (count/L) }\end{array}$ & $\begin{array}{l}\text { G. lamblia } \\
\text { (count/L) }\end{array}$ & $\begin{array}{l}\text { Microsporidia } \\
\text { (count/L) }\end{array}$ & $\begin{array}{c}\text { FC } \\
(\mathrm{cfu} / \mathrm{mL})\end{array}$ \\
\hline 10 Sep & 1 & 0 & 0 & 30 \\
\hline 9 Oct & 5 & 1 & 0 & 30 \\
\hline 9 Oct & 3 & 0 & 0 & $>300$ \\
\hline 28 Oct & NS & NS & NS & 262 \\
\hline $28 \mathrm{Oct}$ & NS & NS & NS & 78 \\
\hline 28 Oct & NS & NS & NS & 17 \\
\hline 29 Oct & NS & NS & NS & 32 \\
\hline 29 Oct & 8 & 3 & 0 & 45 \\
\hline 29 Oct & NS & NS & NS & $>300$ \\
\hline $24 \mathrm{Nov}$ & NS & NS & NS & 0 \\
\hline $27 \mathrm{Nov}$ & NS & NS & NS & 0 \\
\hline $27 \mathrm{Nov}$ & NS & NS & NS & 4 \\
\hline $27 \mathrm{Nov}$ & NS & NS & NS & 3 \\
\hline $27 \mathrm{Nov}$ & NS & NS & NS & 69 \\
\hline $27 \mathrm{Nov}$ & NS & NS & NS & 27 \\
\hline $1 \mathrm{Dec}$ & NS & NS & NS & 14 \\
\hline $1 \mathrm{Dec}$ & NS & NS & NS & 48 \\
\hline $1 \mathrm{Dec}$ & NS & NS & NS & 199 \\
\hline $1 \mathrm{Dec}$ & NS & NS & NS & 182 \\
\hline $1 \mathrm{Dec}$ & NS & NS & NS & 97 \\
\hline $4 \mathrm{Dec}$ & NS & NS & NS & 76 \\
\hline $4 \mathrm{Dec}$ & NS & NS & NS & 27 \\
\hline $4 \mathrm{Dec}$ & NS & NS & NS & 0 \\
\hline $4 \mathrm{Dec}$ & NS & NS & NS & $>300$ \\
\hline $4 \mathrm{Dec}$ & NS & NS & NS & 47 \\
\hline $5 \mathrm{Dec}$ & NS & NS & NS & 37 \\
\hline 12 Jan & NS & NS & NS & 54 \\
\hline 12 Jan & NS & NS & NS & $>300$ \\
\hline 12 Jan & NS & NS & NS & 4 \\
\hline 12 Jan & NS & NS & NS & $>300$ \\
\hline 12 Jan & NS & NS & NS & 140 \\
\hline 12 Jan & NS & NS & NS & $>300$ \\
\hline 12 Jan & NS & NS & NS & $>300$ \\
\hline
\end{tabular}

Each shop was sampled on 1 occasion.

$F C=$ faecal coliform; $N S=$ not sampled. 


\begin{tabular}{|c|c|c|c|c|}
\hline Date sampled & $\begin{array}{l}\text { C. parvum } \\
\text { (count/L) }\end{array}$ & $\begin{array}{l}\text { G. lamblia } \\
\text { (count/L) }\end{array}$ & $\begin{array}{l}\text { Microsporidia } \\
\text { (count/L) }\end{array}$ & $\begin{array}{c}\text { FC } \\
(\mathrm{cfu} / \mathrm{mL})\end{array}$ \\
\hline \multicolumn{5}{|l|}{ Preschool 1} \\
\hline 6 Oct & NS & NS & NS & 48 \\
\hline 6 Oct & NS & NS & NS & $>300$ \\
\hline \multicolumn{5}{|l|}{ Preschool 2} \\
\hline 23 Sep & 1 & 1 & 0 & 159 \\
\hline $14 \mathrm{Nov}$ & NS & NS & NS & 253 \\
\hline $14 \mathrm{Nov}$ & NS & NS & NS & 12 \\
\hline $26 \mathrm{Dec}$ & 0 & 0 & 0 & $>300$ \\
\hline \multicolumn{5}{|l|}{ Preschool 3} \\
\hline 23 Sep & 1 & 0 & 0 & $>300$ \\
\hline 6 Oct & 1 & 2 & 0 & $>300$ \\
\hline 6 Oct & NS & NS & NS & $>300$ \\
\hline $26 \mathrm{Dec}$ & 0 & 0 & 0 & $>300$ \\
\hline \multicolumn{5}{|l|}{ Preschool 4} \\
\hline $17 \mathrm{Nov}$ & NS & NS & NS & 223 \\
\hline 17 Nov & NS & NS & NS & $>300$ \\
\hline \multicolumn{5}{|l|}{ Preschool 5} \\
\hline 19 Nov & NS & NS & NS & 0 \\
\hline 19 Nov & NS & NS & NS & 126 \\
\hline \multicolumn{5}{|l|}{ Preschool 6} \\
\hline $17 \mathrm{Nov}$ & NS & NS & NS & $>300$ \\
\hline 17 Nov & NS & NS & NS & $>300$ \\
\hline \multicolumn{5}{|l|}{ Preschool 7} \\
\hline 6 Oct & NS & NS & NS & 159 \\
\hline 6 Oct & NS & NS & NS & $>300$ \\
\hline \multicolumn{5}{|l|}{ Preschool 8} \\
\hline 6 Oct & NS & NS & NS & 132 \\
\hline 6 Oct & NS & NS & NS & $>300$ \\
\hline
\end{tabular}

Results for service water samples are italicized. $F C=$ faecal coliform; $N S=$ not sampled .

value of $8.4 ; P=0.004)$. The odds of finding parasites in FC-contaminated water were 2.5 times the odds (95\% confidence interval: 1.64-2.94) of finding parasites when the water was FC-free.

\section{Discussion}

Drinking water in Shatila was contaminated, from sources to intermediaries to end users, although the level of contamination varied, decreasing as the water was processed by the water vendors, then increasing as water was distributed to water shops and preschools.

No relationship was found between FC and parasite levels. The water received by water shops was contaminated despite the reported efforts by vendors to treat the water. It is possible that shop owners were not effectively cleaning their water storage containers. Overall, the quality of water sold at these shops was either similar or worse in quality than the water vendor source.

Most preschools had high FC concentrations $(>300 \mathrm{cfu} / \mathrm{mL})$ in drinking water. Water from two of the schools was contaminated intermittently with parasites. Contamination of the water supply at Shatila occurs against a backdrop of high rates of infectious diseases (20-60\% in different studies) among Palestinian refugee children (23).

Al-Hindi noted in 2002 that the occurrence of gastrointestinal parasites in Palestinian children was common, and that refugees living in camps fared worse than those living in cities (24). Poor living and health conditions of Palestinian refugees are linked and are conducive to disease, especially among the most vulnerable (25). Our study shows that 
contaminated drinking water should be considered an important route of exposure, especially in Shatila and areas with similar water system problems.

Extreme precipitation can greatly increase the levels of microbial contamination in source waters and waterborne outbreaks often occur following extreme rainfall (26). FC concentration is considered by the WHO and United States Environmental Protection Agency to have limited utility. Some viruses and all protozoa are more resistant than FCs to disinfection; therefore, the absence of FCs does not guarantee the absence of these organisms. Moreover, one may find $\mathrm{FC}$ s of animal origin in the complete absence of detectable human pathogens; especially in the context of single sampling. Other factors further complicate the indicator system and the task of accurately gauging drinking water quality conditions and related health risks (27).

Parasites are highly infective, even when present in low numbers. It is important to note that the methods used to analyse these organisms generally have low recovery efficiency (up to $45 \%$ ), thereby underestimating concentrations (28). Monitoring for these parasites confirmed that the water in Shatila was contaminated with pathogens. Recovery of G. lamblia and C. parvum is reported to average $27 \%$, compared with $42 \%$ for microsporidia (29).

These parasitic pathogens are commonly encountered in sewage effluent, surface and groundwater in North America as well as internationally. $G$. lamblia has been found in the range of 10 000-100 000 cysts/L in untreated and 10-100 cysts/L in treated sewage, and $\leq 10$ cysts in surface and tap water (30). Microsporidia survives for long periods in wildlife (31). LeChevallier et al reported oocysts of Giardia and Cryptosporidium species in $60.2 \%$ of surface water in the United States of America and Canada (32), and oocysts in $4.5 \%$ of raw water and $3.5 \%$ of treated water samples. They also found C. parvum in 5\% of vertical groundwater wells and $45 \%$ of horizontal wells. Thus, the presence of these pathogens in finished drinking water supplies in Shatila Camp is most likely indicative of contamination by human waste as well as inadequate treatment.

This research identified several potential contributors to the contaminated water in Shatila Camp, including: illegal connections, lack of well protection, lack of "ownership" of public wells/ inadequate maintenance, intermittent operation of wells, shallow wells, poor sewerage infrastructure, lack of education and technical expertise, lack of adequate disinfection and filtration, lack of monitoring, and unsanitary handling and storage of water. Other factors may not have been identified, given that we relied on self-reports from water vendors and others.

Access to safe water is a universal human right and is essential to the wellbeing of populations, especially those who are marginalized, like Palestinian refugees in Shatila Camp. Although improving the water systems in the camp is an important first step, improved drinking water is not necessarily safe drinking water (33,34). Many issues need to be addressed to achieve a safe drinking water system in Shatila, including: improving infrastructure; providing adequate well protection, operation and maintenance; addressing adequate treatment (disinfection and filtration) techniques; monitoring; increasing technical expertise; and educating about water and health.

The PC in the camp will need to take action to provide clean water to its community, starting with sharing the water quality results. Lack of education was evident through the reflections and actions of many constituents, and this should be a focus for future interventions to address the potential causes of water contamination at the community level.

\section{Acknowledgements}

We give special thanks to Peter Lees, William Brieger and Paul Locke for providing guidance and support and Dr. Elizabeth Coluantoni for assisting with the statistical analysis. We are grateful to the Faculty of the American University of Beirut (Dr. Iman Nuwayhid, Ms. Rola Ajib and Mr. Ali Abdul-Razek) who served as scientific advisors, granted access to laboratory facilities and assisted with data sampling and analysis. We thank the Popular Committees at Shatila Refugee Camp and Najdeh Association who facilitated this work.

Funding: Mr. Saeed Khoury and Mr. Tayseer Barakat provided financial support, as well as: Proctor and Gamble, The ARCS (Achievement Rewards for College Scientists) Foundation, the Bloomberg School Dean's Alumni Advisory Council Scholarship and the Department of Homeland Security PACER Scholarship Program.

Competing interests: None declared.

\section{References}

1. Progress on sanitation and drinking water. Geneva: World Health Organization and United Nations Children's Fund; 2015.

2. Prüss-Ustün A, Bartram J, Clasen T, Colford JM Jr, Cumming $\mathrm{O}$, Curtis $\mathrm{V}$, et al. Burden of disease from inadequate water, sanitation and hygiene in low- and middle-income settings: a retrospective analysis of data from 145 countries. Trop Med Int Health. 2014 Aug;19(8):894-905. PMID:24779548

3. Ugland OF, ed. Difficult past, uncertain future: living conditions among Palestinian refugees in camps and gatherings in Leba- 
non 2003 (http://almashriq.hiof.no/general/300/320/327/ fafo/reports/409.pdf, accessed 25 August 2016).

4. United Nations Relief and Works Agency. Palestine refugee camp profiles 2014 (http://www.unrwa.org/where-we-work/ lebanon/camp-profiles?field=15, accessed 25 August 2016).

5. Jacobson LB, ed. Finding means: UNRWA's financial crisis and refugee living conditions. Volume I: socio-economic situation of Palestinian refugees in Jordan, Lebanon, Syria and the West Bank and Gaza Strip (http://almashriq.hiof.no/ general/300/320/327/fafo/reports/427-vol1.pdf, accessed 25 August 2016).

6. Zeidan A. Environmental conditions in Palestinian camps in Lebanon - case study. 1999 (http://prrn.mcgill.ca/research/ papers/zeidan.htm, accessed 25 August 2016).

7. Cabral JP. Water microbiology. Bacterial pathogens and water. Int J Environ Res Public Health. 2010 Oct;7(10):3657-703. PMID:21139855

8. Robertson LJ, Campbell AT, Smith HV. Survival of Cryptosporidium parvum oocysts under various environmental pressures. Appl Environ Microbiol. 1992 Nov;58(11):3494-500. PMID:1482175

9. Finch GR, Black EK, Labatiuk CW, Gyürék L, Belosevic M. Comparison of Giardia lamblia and Giardia muris cyst inactivation by ozone. Appl Environ Microbiol. 1993 Nov;59(11):3674-80. PMID:8285675

10. Korich DG, Mead JR, Madore MS, Sinclair NA, Sterling CR. Effects of ozone, chlorine dioxide, chlorine, and monochloramine on Cryptosporidium parvum oocyst viability. Appl Environ Microbiol. 1990 May;56(5):1423-8. PMID:2339894

11. deRegnier DP, Cole L, Schupp DG, Erlandsen SL. Viability of Giardia cysts suspended in lake, river, and tap water. Appl Environ Microbiol. 1989 May;55(5):1223-9. PMID:2757381

12. Cacciò SM, Thompson RC, McLauchlin J, Smith HV. Unravelling Cryptosporidium and Giardia epidemiology. Trends Parasitol. 2005 Sep;21(9):430-7. PMID:16046184

13. Exner M, Gornik V. Durch trinkwasser übertragene parasitäre zoonosen [Parasitic zoonoses transmitted by drinking water. Giardiasis and cryptosporidiosis]. Bundesgesundheitsblatt Gesundheitsforschung Gesundheitsschutz. 2004 Jul;47(7):698704. PMID:15254826

14. Arani AS, Alaghehbandan R, Akhlaghi L, Shahi M, Lari AR. Prevalence of intestinal parasites in a population in south of Tehran, Iran. Rev Inst Med Trop Sao Paulo. 2008 May-Jun;50(3):145-9. PMID:18604414

15. Harhay MO, Horton J, Olliaro PL. Epidemiology and control of human gastrointestinal parasites in children. Expert Rev Anti Infect Ther. 2010 Feb;8(2):219-34. PMID:20109051

16. Savioli L, Smith H, Thompson A. Giardia and Cryptosporidium join the 'Neglected Diseases Initiative'. Trends Parasitol. 2006 May;22(5):203-8. PMID:16545611

17. World Health Organization. Measuring chlorine levels in water supplies (http://www.who.int/water_sanitation_health/ publications/2011/WHO_TN_11_Measuring_chlorine_levels_in_water_supplies.pdf, accessed 25 August 2016).

18. American Public Health Association, American Waterworks Association and Water Environment Federation. Method 9222: membrane filter technique for members of the coliform group, in standard methods for examination of water and wastewater. 22nd ed. Washington DC: American Public Health Association; 2012.
19. Guidelines for drinking water quality, 4th ed. Geneva: World Health Organization; 2011 (http://whqlibdoc.who.int/publications/2011/9789241548151_eng.pdf?ua=1, accessed 25 August 2016).

20. Lebanon Ministry of Environment. Drinking-water surface water used as a source for drinking after treatment. In: Standards for the minimization of pollution of air, water and soil. Beirut: Lebanon Ministry of Environment; 1996.

21. Graczyk TK, Grimes BH, Knight R, Da Silva AJ, Pieniazek NJ, Veal DA. Detection of Cryptosporidium parvum and Giardia lamblia carried by synanthropic flies by combined fluorescent in situ hybridization and a monoclonal antibody. Am J Trop Med Hyg. 2003 Feb;68(2):228-32. PMID:12641416

22. Ash LR, Orihel TC. Parasites. A guide to laboratory procedures and identification. Chicago: American Society of Clinical Pathologists; 1987.

23. Laham NA, Elyazji M, Al-Haddad R, Ridwan F. Prevalence of enteric pathogen-associated community gastroenteritis among kindergarten children in Gaza. J Biomed Res. 2015 Jan;29(1):61-8. PMID:25745477

24. Al-Hindi Al. Prevalence of intestinal parasites among school children in Deir El-Balah Town in Gaza Strip, Palestine. Ann Saudi Med. 2002 May-Jul;22(3-4):273-5. PMID:17159426

25. Zabaneh JE, Watt GC, O'Donnell CA. Living and health conditions of Palestinian refugees in an unofficial camp in the Lebanon: a cross-sectional survey. J Epidemiol Community Health. 2008 Feb;62(2):91-7. PMID:18192595

26. Curriero FC, Patz JA, Rose JB, Lele S. The association between extreme precipitation and waterborne disease outbreaks in the United States, 1948-1994. Am J Public Health. 2001 Aug;91(8):1194-9. PMID:11499103

27. Noble RT, Leecaster MK, McGee CD, Weisberg SB, Ritter K. Comparison of bacterial indicator analysis methods in stormwater-affected coastal waters. Water Res. 2004 Mar;38(5):11838. PMID:14975651

28. Zarlenga DS, Trout JM. Concentrating, purifying and detecting waterborne parasites. Vet Parasitol. 2004 Dec 9;126(1-2):195217. PMID:15567585

29. Moss JA, Gordy J, Snyder RA. Effective concentration and detection of Cryptosporidium, Giardia, and the microsporidia from environmental matrices. J Pathog. 2014;2014:408204. PMID:25295196

30. Method 1623: Cryptosporidium and Giardia in Water by Filtration/IMS/FA. United States Environmental Proterction Agency; 2005 (https://www.epa.gov/sites/production/files/2015-08/ documents/method_1623_2005.pdf, accessed 6 September 2016).

31. Fayer R, Santín M, Trout JM, DeStefano S, Koenen K, Kaur T. Prevalence of microsporidia, Cryptosporidium spp., and Giardia spp. in beavers (Castor canadensis) in Massachusetts. J Zoo Wildl Med. 2006 Dec;37(4):492-7. PMID:17315434

32. LeChevallier MW, Norton WD, Lee RG. Occurrence of Giardia and Cryptosporidium spp. in surface water supplies. Appl Environ Microbiol. 1991 Sep;57(9):2610-6. PMID:1822675

33. Bain R, Cronk R, Wright J, Yang H, Slaymaker T, Bartram J. Fecal contamination of drinking-water in low- and middle-income countries: a systematic review and meta-analysis. PLoS Med. 201405 06;11(5):e1001644. PMID:24800926

34. Onda K, LoBuglio J, Bartram J. Global access to safe water: accounting for water quality and the resulting impact on MDG progress. Int J Environ Res Public Health. 2012 Mar;9(3):88094. PMID:22690170 